УДК 631.445.4:631.41(470.32)

DOI: $10.18101 / 2542-0623-2020-3 / 4-44-59$

\title{
ТЯЖЕЛЫЕ МЕТАЛЛЫ В РАСТЕНИЯХ НА ТЕРРИТОРИИ ДЕЯТЕЛЬНОСТИ ДЖИДИНСКОГО ВОЛЬФРАМО-МОЛИБДЕНОВОГО КОМБИНАТА (ЗАПАДНОЕ ЗАБАЙКАЛЬЕ)
}

С. Б. Сосорова, И. Н. Лаврентьева, Л. Н. Болонева, В. Л. Убугунов, Э. Г. Цыремпилов

\section{(C) Сосорова Соелма Батожаргаловна}

кандидат биологических наук,

Институт общей и экспериментальной биологии СО РАН

Россия, 670047, г. Улан-Удэ, ул. Сахьяновой, 6

soelma_sosorova@mail.ru

\section{(C) Лаврентьева Ирина Николаевна}

кандидат биологических наук,

Институт общей и экспериментальной биологии СО РАН Россия, 670047, г. Улан-Удэ, ул. Сахьяновой, 6

lira1973@mail.ru

\section{(c) Болонева Людмила Николаевна}

кандидат биологических наук,

Институт общей и экспериментальной биологии СО РАН

Россия, 670047, г. Улан-Удэ, ул. Сахьяновой, 6

ldm-boloneva@mail.ru

\section{() Убугунов Василий Леонидович}

Кандидат биологических наук,

Институт общей и экспериментальной биологии СО РАН

Россия, 670047, г. Улан-Удэ, ул. Сахьяновой, 6

ubugunovv@mail.ru

\section{(C) Цыремпилов Энхэ Галсанович}

кандидат биологических наук,

Институт общей и экспериментальной биологии СО РАН

Россия, 670047, г. Улан-Удэ, ул. Сахьяновой, 6

enhetsyrempilov@mail.ru

Аннотация. Исследованы уровни концентрации тяжелых металлов (ТМ) в растениях территории деятельности Джидинского вольфрамо-молибденового комбината (Западное Забайкалье). Объектами исследования являлись растения, произрастающие на аллювиальной темногумусовой почве (Fluvisols) - фоновый участок, техногенном песке и почвогрунтах рекультивированных участков. Содержание обменной формы $\mathrm{TM}$ превышало ПДК по $\mathrm{Cd}, \mathrm{Cu}, \mathrm{Ni}$ и $\mathrm{Zn}$ в почвогрунтах рекультивированных участков, 
Сосорова С. Б., Лаврентьева И. Н., Болонева Л. Н., Убугунов В. Л., Цыремпилов Э. Г. Тяжелые металлы в растениях на территории деятельности Джидинского вольфрамо-молибденового комбината

по $\mathrm{Cr}$, $\mathrm{Ni}$ и $\mathrm{Pb}$ - в техногенном песке и не превышало в фоновой почве. Концентрация ТМ в растениях имела различный уровень и вариабельность. Установлено, что в надземной части растений рекультивированных контуров концентрации ТМ в большинстве случаев превышали их средние содержания в растительности континентов. Для растений на участке техногенного песка это превышение отмечалось в отношении $\mathrm{Cd}$, Мо и $\mathrm{Pb}$, а на фоновом участке - $\mathrm{Cd}, \mathrm{Co}, \mathrm{Mo} \mathrm{и} \mathrm{Pb}$. В целом относительно высокое содержание ТМ определено в надземной массе растений, произрастающих на контуре № 1, а минимальное - на фоновом участке и техногенном песке. Концентрация элементов в подземной массе значительно выше, чем в надземной массе. В подземной массе растений относительно максимальная концентрация выявлена на контуре № 1 и техногенном песке, а минимальная - на фоновом участке. $\mathrm{Mn}, \mathrm{Zn}, \mathrm{Cu}$ и Рb являются доминантами по содержанию в растениях. Уровни концентрации ТМ в растениях имели зависимость от уровня содержания их подвижных форм. Значения коэффициента биогеохимической подвижности (Bх) имели широкий диапазон колебаний для подземной массы и относительно узкий для надземной массы. Доступные формы Mo, Zn активно извлекались растениями $(\mathrm{Bx}>1)$. На фоновом участке растения активно поглощали и перемещали в надземную часть $\mathrm{Cd}, \mathrm{Cu}, \mathrm{Mo}, \mathrm{Pb}, \mathrm{Zn}$. Большинство изученных элементов $(\mathrm{Cd}, \mathrm{Co}, \mathrm{Cu}$, $\mathrm{Mn}, \mathrm{Ni}, \mathrm{Cr}$ ) имели значение $\mathrm{Bx}<1$.

Ключевые слова: тяжелые металлы; растение; загрязнение; почвогрунты; техногенный песок; фоновый участок.

\section{Для цитирования}

Тяжелые металлы в растениях на территории деятельности Джидинского вольфрамомолибденового комбината (Западное Забайкалье) / С. Б. Сосорова [и др.] // Природа Внутренней Азии. Nature of Inner Asia. 2020. № 3/4(16). С. 44-59.

DOI: $10.18101 / 2542-0623-2020-3 / 4-44-59$

\section{Введение}

Одним из основных источников техногенного поступления тяжелых металлов (TM) в биосферу является горнорудная промышленность. В результате деятельности горнодобывающих предприятий возникают техногенные ландшафты, которые оказывают негативное воздействие на окружающую среду [Gerasimova, Eremina, Kuklina, 2020]. Не является исключением и Республика Бурятия, на территории которой также ведется разработка полезных ископаемых: разрезы «Тугнуйский», «Холбольджинский», бывший Джидинский вольфрамо-молибденовый комбинат (ДВМК) и т. д.

Так, в результате деятельности ДВМК произошло значительное загрязнение ТМ компонентов окружающей среды (воздух, вода, почва, растения), оказавшее негативное воздействие на здоровье население г. Закаменск. В частности, в результате сброса шахтных и дренажных вод, а также ливневых стоков от хвостохранилищ, значительные количества ТМ, фтора, сульфатов мигрируют в поверхностные воды бассейна рек Джида и Модонкуль [Бардамова, Гергенов, 2012].

Джидинское вольфрамо-молибденовое месторождение расположено на водоразделе притоков реки Джида - Модонкуль и Маргын-Шено в северных отрогах Джидинского хребта. ДВМК перерабатывал молибденитовые и сульфидно-гюбнеритовые руды Первомайского, Холтосонского и Инкурского месторождений Джидинского рудного поля на протяжении более 60 лет. За период работы комбината накоплено около 50 млн т отходов в виде техногенного песка, что, в свою очередь, 
оказывало негативное воздействие на окружающую среду [Дорошкевич и др., 2016]. В 1998 г. комбинат был закрыт.

Вопросы реабилитации территорий деятельности ДВМК, восстановления экологического баланса и мелиорации деградированных земель возникли после прекращения его эксплуатации и до сих пор не решены. В 2011 г. после закрытия комбината в Бурятии начались мероприятия по ликвидации ущерба в рамках Федеральной целевой программы «Охрана озера Байкал», которая рассчитана до 2020 г. С 2013 по 2017 г. были реализованы мероприятия по рекультивации земель на территории г. Закаменска.

В результате реализации проектных мероприятий пески Джидинского хвостохранилища в объеме $2095801 \mathrm{~m}^{3}$ были вывезены и размещены в БарунНарынском хвостохранилище. Проведена техническая и биологическая рекультивация нарушенных горным производством земель в приустьевой части реки Модонкуль до правобережья реки Джида. Расчищен участок р. Модонкуль от места ее выхода из города Закаменск до автомобильного моста через р. Модонкуль, отведены грунтовые воды с территории с целью недопущения возникновения наледей р. Модонкуль [Дмитриева, 2018].

Кратко геоэкологическая оценка рекультивированных территорий деятельности Джидинского вольфрамо-молибденового комбината дана в работе С. Б. Сосорова и др. (2018) и до проведения рекультивационных работ А. Б. Иметхенов, О. А. Иметхенов, О. В. Иметхенова (2016).

Растения являются промежуточным звеном в поступлении химических элементов в организмы человека и животных, накапливая различное количество ТМ в соответствии с уровнем техногенной нагрузки и физиологическими особенностями вида [Ильин, Сысо, 2012, Минкина и др., 2013]. Как указывают Ф. Е. Козыбаева, Э. А. Мурсалимова (2004) увеличение процессов техногенного загрязнения экосистем способствует аккумуляции ТМ в растениях.

В этой связи целью нашей работы была оценка уровня накопления ТМ и их биогеохимической подвижности в растениях рекультивированных участков территории воздействии ДВМК.

\section{Материалы и методики исследований}

С целью изучения уровня концентрации ТМ ( $\mathrm{Cr}, \mathrm{Ni}, \mathrm{Mn}, \mathrm{Zn}, \mathrm{Cu}, \mathrm{Co}, \mathrm{Pb}, \mathrm{Cd}, \mathrm{Mo})$ в компонентах техногенных ландшафтов были исследованы почвы, почвогрунты и растительность территорий деятельности бывшего ДВМК.

Объектами исследований являлись аллювиальная темногумусовая почва фонового участка, почвогрунты рекультивированных участков, прилегающих к г. Закаменск (контуры № $1,3,4)$, и произрастающие на них растения.

Физические и агрохимические свойства почв, почвогрунтов и техногенного песка изучены по следующим методикам: гранулометрический состав - пипеточным методом (ГОСТ 12536-2014), $\mathrm{pH}$ водной и солевой вытяжек - потенциометрическим методом, обменные кальций и магний - комплексонометрическим методом (ГОСТ 26487-85), емкость катионного обмена - по Бобко-Аскинази-Алешину в модификации ЦИНАО (ГОСТ 17.4.4.01-84), углерод гумуса — по Тюрину в модификации Никитина, общий азота - по Къельдалю (ГОСТ 26107- 84), подвижный $\mathrm{P}_{2} \mathrm{O}_{5}$ и обменный $\mathrm{K}_{2} \mathrm{O}$ - по Кирсанову (ГОСТ Р 54650-2011, стандарт не 
распространяется на почвенные горизонты, содержащие карбонаты) и по Мачигину (ГОСТ 26205-91 в карбонатных почвах).

Растительные образцы представляли собой усредненные пробы укосов трав, произраставших на исследованных площадках, которые включали надземные и подземные части растений. ТМ в растительных образцах определяли атомно-адсорбционным методом на приборе Perkin Elmer (США) после сухого озоления пробы при $450^{\circ} \mathrm{C}$ и последующего растворения остатка в смеси кислот $\mathrm{HNO} 3+$ $\mathrm{HCl}$ [Методические указания... 1992]. Уровни предельно допустимых концентраций (ПДК) и ориентировочно допустимых концентраций (ОДК) даны по Гигиеническим нормативам ГН 2.1.7.2041-06 «Предельно допустимые концентрации химических веществ в почве» и ГН 2.1.7.2511-09 «Ориентировочно допустимые концентрации (ОДК) химических веществ в почве». Для оценки активности извлечения ТМ из почв растениями проводился расчет коэффициента биологической подвижности - Вх, представленного отношением содержания ТМ в сухом веществе растения к содержанию его подвижной формы в субстрате [Перельман, Касимов, 2000]. Экспериментальные данные были подвергнуты вариационно-статистической обработке с использованием программ Microsoft Excel 97.

Фоновую почву изучали в окрестностях г. Закаменск, выше по течению p. Джида на участке луговой выровненной поймы. Географические координаты места закладки пробной площадки: 50²4'09,1" с. ш., 103º'16'20,1" в. д. Почва аллювиальная темногумусовая квазиглееватая криотурбированная постагрогенная согласно классификации [Классификация... 2004]. Изученная почва имела неоднородный гранулометрический состав с преобладанием мелкопесчаной или крупнопылеватой фракции: гумусовый и погребенные горизонты суглинистые, а иллювиальные горизонты и подстилающая почвообразующая порода - супесчаный или песчаный.

Почва характеризовалась слабокислой реакцией среды, переходящей с глубиной в слабощелочную, высоким содержанием суммы поглощенных оснований в гумусовом и погребенных горизонтах. Поглощающий комплекс преимущественно насыщен кальцием. Содержание гумуса и общего азота в верхнем горизонте низкое.

Растительное сообщество - разнотравно-монгольскополевицевый луг, во флористическом составе которого насчитывалось три вида злаков и 36 бобовых. Проективное покрытие достигало 90-95\%.

На части нарушенных деятельностью ДВМК территориях (в приустьевой части реки Модонкуль до правобережья реки Джида, три контура) проведена техническая и биологическая рекультивация.

Контур № 1. Координаты $50^{\circ} 21^{\prime} 52,2^{\prime \prime}$ с. ш., $103^{\circ} 17^{\prime} 20,1^{\prime \prime}$ в. Д. - $50^{\circ} 22^{\prime} 02,1 "$ с. ш., $103^{\circ} 17^{\prime} 21,7^{\prime \prime}$ в. д. Поверхность контура полностью освобождена от техногенного песка на площади 23,8 га. После на данной территории были высажены саженцы лиственницы сибирской (Larix Sibirica) и березы повислой (Bétula péndula) в посадочные ямы, заполненные плодородным компостным грунтом.

На контуре № 1 растительный покров образован полынными, марьевыми, гривастоячменно-пырейными группировками растений, техногенными пустошами с фрагментами группировок марьевой, разнотравно-вострецовой сообществами и лесополосами из лиственницы сибирской и березы повислой. 


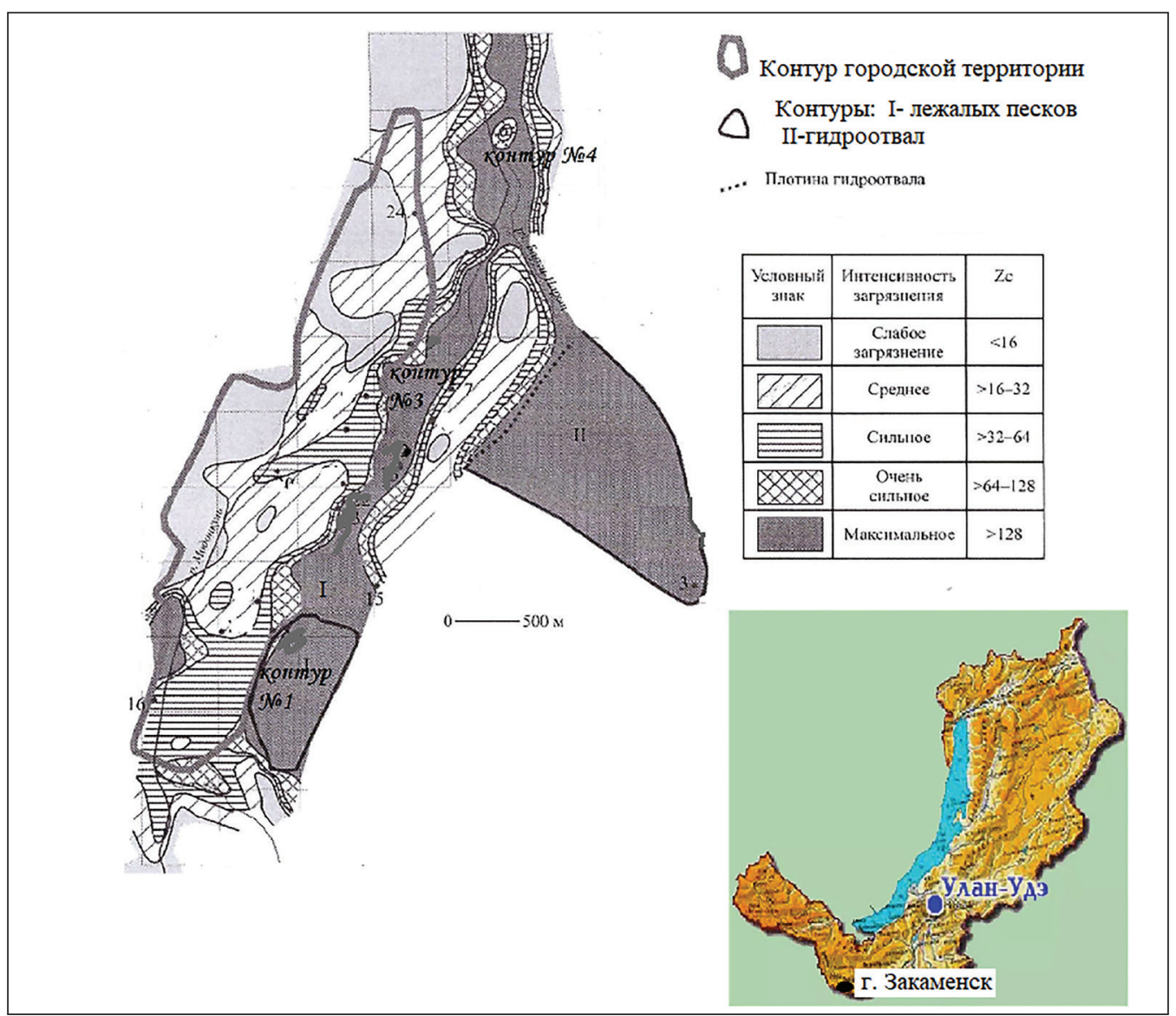

Puc. 1. Картосхема района исследования по [Дорошкевич и др., 2016] с авторскими дополнениями

Почвогрунты контура № 1 имели легко- или среднесуглинистый гранулометрический состав с преобладанием мелкопесчаной или крупнопылеватой фракций. В среднем верхний 10-сантиметровый слой контура - легкосуглинистый с содержанием частиц $<0,01$ мм - 23,8 $\pm 1,6 \%$. При этом в пределах площадок трех точек: 1-1, 1-2 и 1-5 встречались локальные супесчаные наносы.

В среднем в 0-10-сантиметровом слое почвогрунтов реакция среды сильнокислая $\left(\mathrm{pH}_{\text {вод. }}=4,7 \pm 0,4\right)$, за исключением площадки т.1-5, где $\mathrm{pH}_{\text {вод }}=7,5$. Высокие показатели гидролитической кислотности отмечаются на трех площадках точек: т. 1-1, 1-2, 1-4. Поэтому необходимо проведение известкования почвогрунтов.

Содержание гумуса по контуру в поверхностном 10-сантиметровом слое варьировало в диапазоне $0,84-3,51 \%$ и в среднем составляло - $2,16 \pm 0,48 \%$. Для почвогрунтов контура характерно очень низкое содержание общего азота.

Распространение карбонатов - локальное - в пределах площадки т.1-5 и на поверхности площадки т.1-1. Содержание подвижного фосфора и обменного калия очень низкое.

Контур № 3. Координаты $50^{\circ} 22^{\prime} 45,8^{\prime \prime}$ с. ш., $103^{\circ} 17^{\prime} 56,0^{\prime \prime}$ в. д. - 50²4'18, $0^{\prime \prime}$ с. ш., $103^{\circ} 18^{\prime} 18,7^{\prime \prime}$ в. д. Проведена частичная техническая и биологическая рекультивация 
Сосорова С. Б., Лаврентьева И. Н., Болонева Л. Н., Убугунов В. Л., Цыремпилов Э. Г. Тяжелые металлы в растениях на территории деятельности Джидинского вольфрамо-молибденового комбината

поверхности. На площади 39,1 га вывезены техногенные пески, поверхность спланирована и создан рекультивационный слой с использованием суглинка. На рекультивированных участках контура посевы тимофеевки луговой (Phleum pratense), мятлика лугового (Poa pratensis). Встречались проплешины в местах, где мощность плодородного слоя небольшая, либо он совсем отсутствует или верхний слой грунта имеет высокую степень каменистости (с т.3-2 по т.3-9). На ключевой площадке т. 3-2 обнаружен 50 см слой оставшихся техногенных песков.

Севернее рекультивированных участков контура имелись частично самозарастающие участки пролювиально-аллювиального шлейфа техногенных песков, выходящих на поверхность общей площадью 38,7 га, где мероприятия по рекультивации не проводились (т. 3-12 по т. 3-18). Растительное сообщество здесь представлено полевицей монгольской (Agrostis mongolica), вейником Лангсдорфа (Calamagrostis langsdorfii) с разнотравьем и подростом Larix Sibirica, Bétula péndula.

На участках, где была проведена частичная техническая и биологическая рекультивация поверхности (площадки с т.3-1 по т.3-11), в среднем верхний 5-сантиметровый слой почвогрунтов имел легкосуглинистый гранулометрический состав (содержание частиц $<0,01$ мм - 24,2 $\pm 2,9 \%$ ), а нижний 5-20-сантиметровый слой - супесчаный (содержание частиц $<0,01$ мм - 18,0 $2,9 \%$ ). В целом по контуру отмечалась высокая пестрота почвогрунтов по гранулометрическому составу.

Значения $\mathrm{pH}_{\text {вол }}$ почвогрунтов исследуемого контура варьировало в широком диапазоне $\left(\mathrm{pH}_{\text {вод }}=3,0-7,6\right)$. При этом погребенные или поверхностные слои техногенного песка имели сильнокислую или кислую реакцию $\left(\mathrm{pH}_{\text {вог }}=3,0-5,2\right)$. В среднем по контуру для слоя 0-10 см данный показатель составлял 5,3 $\pm 0,2$.

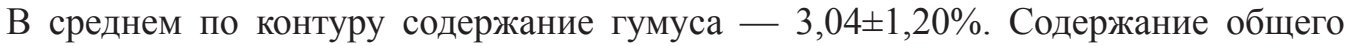
азота в почвогрунте низкое, за исключением первых площадок.

Среднее содержание по контуру подвижного фосфора $(6,4 \pm 0,7$ мг/кг) и обменного калия $(2,8 \pm 0,3$ мг/кг) очень низкое.

Контур № 4. Координаты $50^{\circ} 25^{\prime} 05,1^{\prime \prime}$ с. ш., $103^{\circ} 17^{\prime} 43,1^{\prime \prime}$ в. Д. — № 50²5'27,5" с. ш., $103^{\circ} 32^{\prime} 04,2^{\prime \prime}$ в. д. На контуре проведена техническая и биологическая рекультивация с гидропосевом травосмеси, состоящей из овсяницы луговой (Festuca pratensis Hudson s.str.), райграса многоукосного (Lolium multiflorum Lam.) и костреца безостого (Bromus inermis Holub).

Для создания плодородного слоя на контуре № 4 мощностью 30 см использовали эфель и суглинок с прилегающей территории. В нижний слой укладывался суглинок мощностью 20 см, поверх него наносился грунт с эфельных отвалов мощностью $10 \mathrm{cm.}$

Характеристика суглинка и эфеля, использованных для создания рекультивационного слоя, приведена в таблице 1.

Таблица 1

\begin{tabular}{|c|c|c|c|c|c|c|c|}
\hline \multicolumn{8}{|c|}{ Свойства эфеля и суглинка } \\
\hline \multirow[b]{2}{*}{ Субстрат } & \multirow[b]{2}{*}{$\begin{array}{c}\text { Фракции } \\
<0.01 \text { мм, \% }\end{array}$} & \multirow[b]{2}{*}{$\mathrm{pH}_{\text {водный }}$} & \multirow[b]{2}{*}{ Гумус, \% } & $\mathrm{Ca}^{2+}$ & $\mathrm{Mg}^{2+}$ & $\mathrm{P}_{2} \mathrm{O}_{5}$ & $\mathrm{~K}_{2} \mathrm{O}$ \\
\hline & & & & \multicolumn{2}{|c|}{ мг-экв/100 г почвы } & \multicolumn{2}{|c|}{$\begin{array}{c}\text { мг/100 г, } \\
\text { по методу } \\
\text { Мачигина }\end{array}$} \\
\hline Эфель & 10 & 6,9 & 0,19 & 6,2 & 2,5 & 1,7 & 4,8 \\
\hline Суглинок & 22 & 7,1 & 1,73 & 26,0 & 6,0 & 1,6 & 4,8 \\
\hline
\end{tabular}


В целом проективное покрытие контура травами очень низкое. Выделялись пространства с редкотравными дернистоосоковыми, полевохвощевыми, незамечаевовейниковыми сообществами и техногенные пустоши.

На пониженных и более увлажненных участках с близким залеганием грунтовых вод проективное покрытие и биопродуктивность растительных сообществ значительно выше. В целом рекультивационный слой (0-10 см) контура № 4 имел супесчаный гранулометрический состав (содержание частиц $<0,01$ мм $-16,9 \pm 1,2$ \%). В среднем отмечали слабощелочную реакцию среды верхнего слоя. Содержание гумуса очень низкое $(0,94 \pm 0,32 \%)$. В соответствии с низким содержанием гумуса наблюдается и низкое содержание общего азота.

Рекультивационный суглинистый слой содержит карбонаты, которые снижают кислотность техногенных песков. Среднее содержание по контуру в верхнем слое почвогрунта (0-10 см) подвижного фосфора $(1,5 \pm 0,7$ мг/кг) и обменного калия $(1,5 \pm 0,3$ мг/кг) очень низкое.

Техногенный песок (координаты $50^{\circ} 25^{\prime} 00,9^{\prime \prime}$ с. ш., $103^{\circ} 18^{\prime} 02,5^{\prime \prime}$ в. д.) характеризовался неблагоприятными свойствами (кислая реакция среды, песчаный гранулометрический состав, очень низкое содержание органического вещества, высокое загрязнение ТМ) и не пригоден для биологической рекультивации (ГОСТ 17.5.1.03-86 Классификация вскрышных и вмещающих пород для биологической рекультивации земель).

Растительность на техногенном песке очень разрежена и представлена небольшими площадями кустарниково-дернистоосоковых сообществ.

\section{Результаты исследования и обсуждение}

Формирование элементного состава почв и растений на исследуемой территории протекает в условиях резко континентального климата, горного рельефа, высокого окислительно-восстановительного потенциала, часто в кислой среде. Н. М. Кожевникова, А. И. Куликов [2010] отмечают, что для почвенного покрова г. Закаменска характерно неуклонное возрастание фонового содержания ТМ, нарушение природного соотношения между ними и локальное накопление их до стадии загрязнения почв. Возможно, это связано с усилением окислительных процессов в техногенных песках и выносом ТМ за пределы хвостохранилища.

Тяжелые металлы в почвогрунтах. Результаты исследования содержания ТМ в почвогрунтах, техногенном песке рассмотрены нами в работе [Сосорова и др., 2018].

Установлено, что наиболее высокие концентрации ТМ характерны для техногенного песка и контура № 1. Содержание $\mathrm{As}, \mathrm{Cd}, \mathrm{Cu}, \mathrm{Mo}, \mathrm{Ni}, \mathrm{Pb}, \mathrm{Sb}, \mathrm{W}, \mathrm{Zn}$ в почвогрунтах рекультивированных участков в основном превышало их фоновые содержания в аллювиальной темногумусовой почве. Многократное превышение по содержанию Mo, W обусловлено наличием геохимической аномалии (месторождение вольфрамо-молибденосодержащих руд).

$\mathrm{Z}_{\mathrm{c}}$ почвогрунтов относительно фонового содержания 15 элементов (As, $\mathrm{Cd}, \mathrm{Co}$, $\mathrm{Cr}, \mathrm{Cu}, \mathrm{Mn}, \mathrm{Mo}, \mathrm{Ni}, \mathrm{Pb}, \mathrm{Sb}, \mathrm{V}, \mathrm{W}, \mathrm{Zn}, \mathrm{Ba}, \mathrm{Sr})$ составляло: контур № $1-170,3$, контур № $3-139,3$, контур № $4-132,1$, техногенный песок - 336,8 и категория загрязнения оценивалась как чрезвычайно опасная, что свидетельствует о критической нагрузке на окружающую среду. 
По уровню суммарного загрязнения ТМ контура можно расположить в следующий ряд по убыванию: контур № $1>$ контур № $3>$ контур № 4 .

Средневзвешенное содержание ТМ в слое 0-10 см исследуемых контуров значительно колебалось, что связано с различием в свойствах почвогрунтов, элементов и их содержанием в компонентах, использованных для создания рекультивационного слоя (эфель, суглинок, плодородный слой почв и т. д.).

Содержание некоторых ТМ превышало как фоновое, так и имеющееся ПДК (ОДК). Высокие концентрации $\mathrm{As}, \mathrm{Cd}, \mathrm{Cu}, \mathrm{Pb}, \mathrm{Sb}, \mathrm{Zn}$, превышающие ПДК (ОДК) в 5,3-12,9 раза и относительно повышенное содержание $\mathrm{Cr}$ выявлены на контуре № 1 .

На контуре № 3 содержания $\mathrm{As}, \mathrm{Cd}, \mathrm{Cu}, \mathrm{Pb}, \mathrm{Zn}$ превышало ПДК (ОДК), по некоторым из них до 16 раз. Содержание $\mathrm{Mn}, \mathrm{Ni}, \mathrm{V}$ на уровне или незначительно превышало ПДК (ОДК). На нерекультивированных участках контура концентрации $\mathrm{Mo}, \mathrm{W}, \mathrm{Pb}$ и $\mathrm{Sb}$ близко к их содержанию в техногенном песке.

На контуре № 4 колебания содержания ТМ в целом имели относительно узкий диапазон, обусловленный однородностью рекультивационного слоя, за исключением $\mathrm{Zn}$ и $\mathrm{Cd}$.

Содержание обменной формы ТМ в фоновой почве не превышало имеющихся ПДК. В почвогрунтах рекультивированных участков отмечалось превышение ПДК по содержанию $\mathrm{Cd}, \mathrm{Cu}, \mathrm{Ni}$ и $\mathrm{Zn}$., в техногенном песке - $\mathrm{Cr}$, $\mathrm{Ni}$ и $\mathrm{Pb}$.

Данное различие в уровнях концентрации ТМ, как отмечает А. В. Писарева и др. (2017), связано с тем, что содержание ТМ в почвах зависит от скорости и интенсивности протекающих в них почвообразовательных процессов и закономерно изменяется от гранулометрического и минералогического состава почв, условий увлажнения и свойств почв.

Наибольшей подвижностью данные ТМ обладают в техногенном песке и почвогрунтах контура № 1, что связано кислой реакцией среды и легким гранулометрическим составом.

Тяжелые металла и микроэлементы в растениях. Аккумуляция ТМ в растениях зависит от содержания поллютантов в почвах и физиологических особенностей самого растения. Поэтому избыточное накопление ТМ растениями обусловлено, прежде всего, их высокими концентрациями в почвах.

Результаты химического анализа растительных образцов исследуемых контуров на содержание ТМ отражены в таблице 2 .

В результате проведенных исследований установлена очень высокая вариабельность содержания ТМ как в надземной, так и в подземной массе растений. Элементами с максимальным содержанием в растениях являются $\mathrm{Mn}, \mathrm{Zn}, \mathrm{Cu}$ и $\mathrm{Pb}$, а с минимальным - $\mathrm{Co}, \mathrm{Cd}$.

По среднему содержанию в растительности ТМ можно расположить в следующий убывающий ряд:

контур № 1 - в надземной массе $\mathrm{Mn}>\mathrm{Zn}>\mathrm{Cu}>\mathrm{Pb}>\mathrm{Ni}>\mathrm{Cr}>\mathrm{Cd}>\mathrm{Mo}>\mathrm{Co}$, в подземной массе $\mathrm{Mn}>\mathrm{Cu}>\mathrm{Zn}>\mathrm{Pb}>\mathrm{Mo}>\mathrm{Ni}>\mathrm{Cr}>\mathrm{Co}>\mathrm{Cd}$;

контур № 3 - в надземной массе $\mathrm{Mn}>\mathrm{Zn}>\mathrm{Mo}>\mathrm{Cr}>\mathrm{Cu}>\mathrm{Ni}>\mathrm{Pb}>\mathrm{Co}>\mathrm{Cd}$, в подземной массе $\mathrm{Mn}>\mathrm{Zn}>\mathrm{Pb}>\mathrm{Cu}>\mathrm{Mo}>\mathrm{Ni}>\mathrm{Cr}>\mathrm{Co}>\mathrm{Cd}$; 
контур № 4 - в надземной массе $\mathrm{Mn}>\mathrm{Zn}>\mathrm{Pb}>\mathrm{Cu}>\mathrm{Mo}>\mathrm{Ni}>\mathrm{Cr}>\mathrm{Co}>\mathrm{Cd}$, в подземной массе $\mathrm{Mn}>\mathrm{Zn}>\mathrm{Cu}>\mathrm{Pb}>\mathrm{Ni}>\mathrm{Cr}>\mathrm{Mo}>\mathrm{Co}>\mathrm{Cd}$;

техногенный песок- в надземной массе $\mathrm{Mn}>\mathrm{Zn}>\mathrm{Cu}>\mathrm{Pb}>\mathrm{Mo}>\mathrm{Cr}>\mathrm{Ni}>$ $\mathrm{Cd}=\mathrm{Co}$, в подземной массе $\mathrm{Mn}>\mathrm{Cu}>\mathrm{Zn}>\mathrm{Pb}>\mathrm{Mo}>\mathrm{Cr}>\mathrm{Ni}>\mathrm{Co}>\mathrm{Cd}$;

фон - в надземной массе $\mathrm{Mn}>\mathrm{Zn}>\mathrm{Cu}=\mathrm{Pb}>\mathrm{Mo}>\mathrm{Cr}>\mathrm{Ni}>\mathrm{Cd}>\mathrm{Co}$, в подземной массе $\mathrm{Mn}>\mathrm{Zn}>\mathrm{Ni}>\mathrm{Pb}>\mathrm{Cu}>\mathrm{Cr}>\mathrm{Co}>\mathrm{Mo}>\mathrm{Cd}$, что в основном связано с их химическими свойствами и биологической ролью. В то же время по уровню накопления $\mathrm{Pb}$ превосходит $\mathrm{Ni}, \mathrm{Cr}$ и $\mathrm{Co}$.

На рекультивированных контурах концентрации ТМ в надземной части растений в большинстве случаев превышали их средние содержания в растительности континентов. Для растений на участке техногенного песка это превышение отмечалось лишь в отношении $\mathrm{Cd}, \mathrm{Mo}$ и $\mathrm{Pb}$, а на фоновом участке - $\mathrm{Cd}, \mathrm{Co}, \mathrm{Mo}$ и $\mathrm{Pb}$.

Максимальные значения содержания $\mathrm{Cd}, \mathrm{Cu}, \mathrm{Pb}, \mathrm{Zn}, \mathrm{Mn}$ выявлены в растениях контура № 1, Мо - контура № 3, $\mathrm{Co}, \mathrm{Cr}, \mathrm{Ni}$ - контура № 4. Концентрация элементов в подземной массе значительно выше, чем в надземной массе (табл. 2, рис. 2).

В растениях контура № 1 наибольшее превышение отмечалось для Мо и $\mathrm{Cu}$. Их количество в подземной массе соответственно в 49 и 21,6 раза превосходило таковое в сухой зеленой массе растений. Для других элементов этот показатель меньше (рис. 2). Наименьшие соотношения установлены для $\mathrm{Zn}-2,7, \mathrm{Cd}-2,2$. Для растений контура № 3 и 4 максимальное превышение выявлено для $\mathrm{Pb}-12,9$ и 84 , минимальное для Мо - 2,9 и 3,0 соответственно.

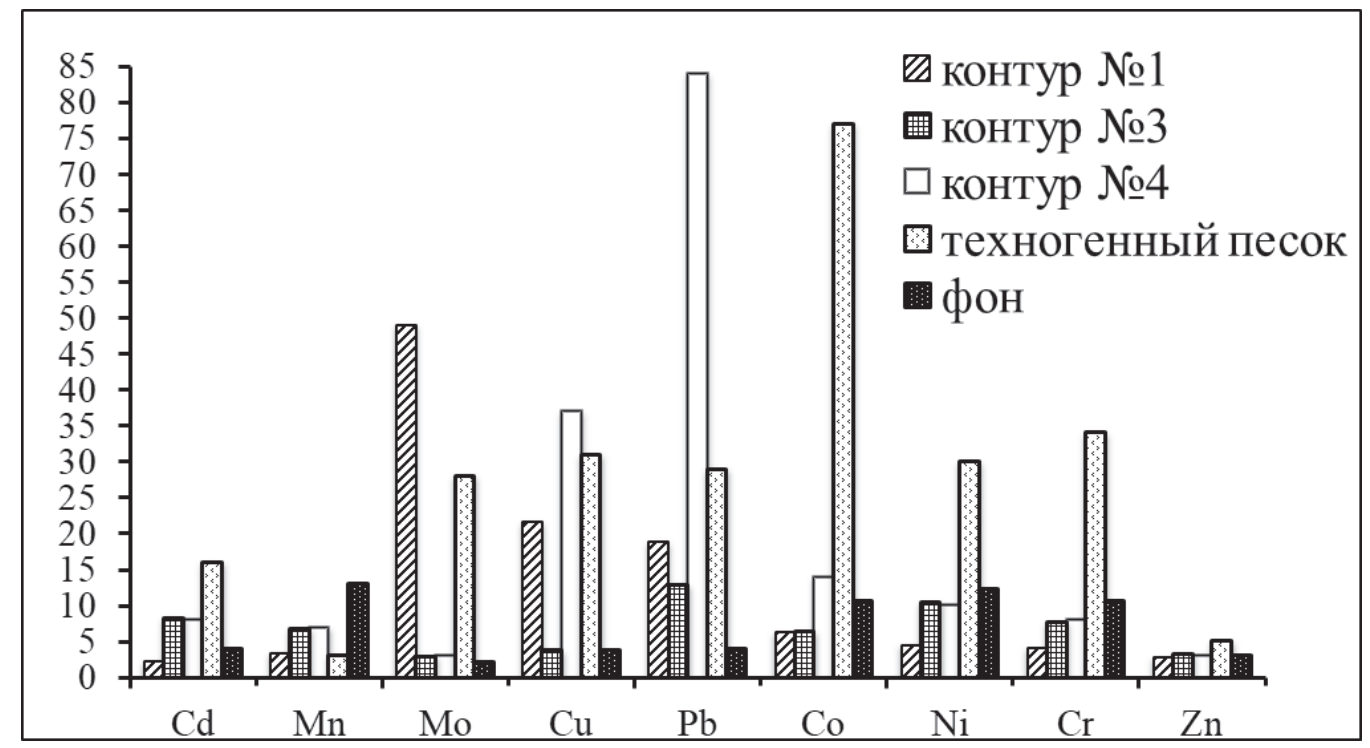

Puc. 2. Соотношение накопления ТМ в надземной и подземной массе растений территорий деятельности ДВМК 
Сосорова С. Б., Лаврентьева И. Н., Болонева Л. Н., Убугунов В. Л., Цыремпилов Э. Г. Тяжелые металлы в растениях на территории деятельности Джидинского вольфрамо-молибденового комбината

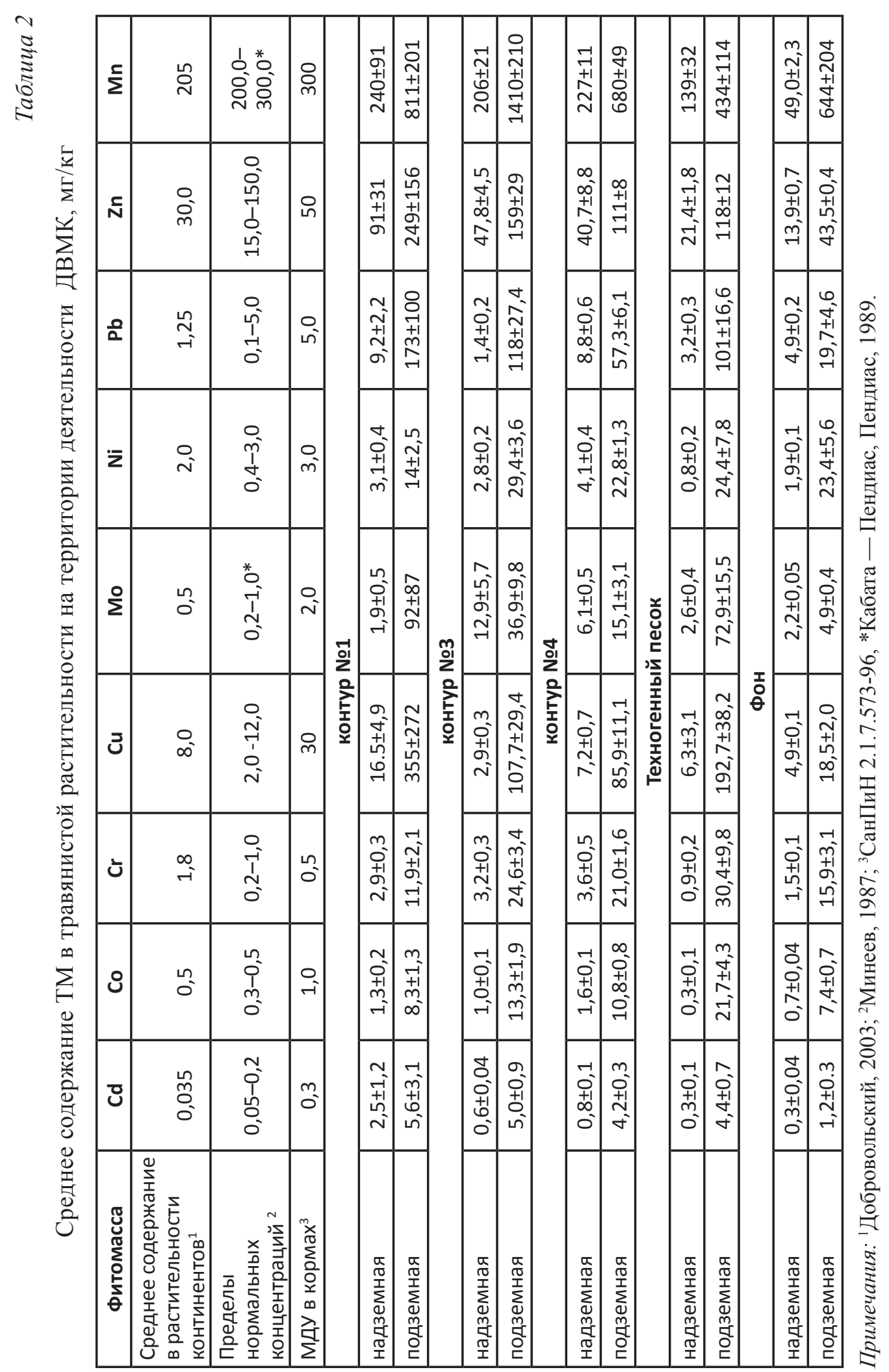


Корни растений, произраставших на техногенном песке, содержали больше Со в 77 раз, $\mathrm{Cr}-34, \mathrm{Cu}-31, \mathrm{Ni}-30, \mathrm{~Pb}-29, \mathrm{Mo}-28, \mathrm{Cd}-16, \mathrm{Zn}-5, \mathrm{Mn}$ - в 3 раза, чем надземная масса. В растениях фонового участка максимальное превышение выявлено для $\mathrm{Mn}-13,1, \mathrm{Ni}-12,3, \mathrm{Co}, \mathrm{Cr}-10,6$, для остальных элементов не превышает 4.

В целом на исследуемой территории наименьшие превышения накопления ТМ в подземной массе выявлены для $\mathrm{Zn}$ и $\mathrm{Mn}$, а наибольшие - $\mathrm{Pb}$ и $\mathrm{Cu}$. Очевидно, что барьерная функция корневой массы естественной растительности, произрастающей в условиях техногенного загрязнения, выражена в большей степени. Уровни концентрации изученных элементов в подземной части растении исследуемой территории превышали пределы нормальных концентраций и значения среднего содержания этих элементов в растительности континентов.

Для надземной части растений установлены превышения максимально допустимого уровня (МДУ) содержания $\mathrm{Cr}$ на всей исследуемой площади, на рекультивированных участках - Cd, а также Со - контур № $1, \mathrm{~Pb}, \mathrm{Mo}-$ контур № 3 , $\mathrm{Co}, \mathrm{Mo}, \mathrm{Ni}, \mathrm{Pb}$ - контур № 4, Мо - техногенный песок, Со - фоновый участок.

Высокая вариабельность в содержании ТМ в растениях связана как с биологическими особенностями растений, так и свойствами почвогрунтов, уровнем содержания в них ТМ.

Объективным критерием оценки аккумуляции ТМ растениями из почвы является коэффициент биогеохимической подвижности (Bх). Это обусловлено тесной связью содержания ТМ в растениях с количеством подвижных форм металлов в почвах [Минкина и др., 2013]. Величина Вх показывает степень «биофильности» химических элементов в реальных условиях, а ее изменение - отклик растений на техногенную нагрузку на почву [Там же]. Как указывают Ф. Е. Козыбаева, Э. А. Мурсалимова (2004) увеличение процессов техногенного загрязнения экосистем способствует аккумуляции ТМ в растениях.

Из таблицы 3 видно, что значения Вх имеют широкий диапазон колебаний для подземной массы, и относительно узкий для надземной массы. По Вх надземной массы исследуемые элементы можно разделить на две группы (табл. 3).

Таблииа 3

Коэффициенты биогеохимической подвижности ТМ в растениях территории деятельности ДВМК

\begin{tabular}{|l|c|c|c|c|c|c|c|c|c|}
\hline Образцы & $\mathrm{Cd}$ & $\mathrm{Co}$ & $\mathrm{Cu}$ & $\mathrm{Mn}$ & $\mathrm{Mo}$ & $\mathrm{Ni}$ & $\mathrm{Pb}$ & $\mathrm{Zn}$ & $\mathrm{Cr}$ \\
\hline $\begin{array}{l}\text { Техногенный } \\
\text { песок }\end{array}$ & $\leq 6,0$ & $\underline{0,14}$ & $\underline{6,6}$ & $\underline{2,10}$ & $\underline{0,29}$ & $\underline{0,13}$ & $\underline{0,10}$ & $\underline{2,61}$ & $\underline{0,13}$ \\
\cline { 2 - 10 } & 88,0 & 10,33 & 192,7 & 9,71 & 8,01 & 3,87 & 3,20 & 14,39 & 4,54 \\
\hline \multirow{2}{*}{ Контур № 1 } & $\underline{0,40}$ & $\underline{0,38}$ & $\underline{0,15}$ & $\underline{0,71}$ & $\underline{9,5}$ & $\underline{0,58}$ & $\underline{0,06}$ & $\underline{0,40}$ & $\underline{0,59}$ \\
\cline { 2 - 10 } & 0,89 & 2,44 & 3,27 & 2,41 & 460 & 2,64 & 1,04 & 1,09 & 2,43 \\
\hline \multirow{2}{*}{ Контур № 3 } & $\underline{0,10}$ & $\underline{0,32}$ & $\underline{0,36}$ & $\underline{0,49}$ & $\underline{8,06}$ & $\underline{0,50}$ & $\underline{0,10}$ & $\underline{1,78}$ & $\underline{0,40}$ \\
\cline { 2 - 10 } & 8,33 & 4,29 & 13,30 & 3,35 & 23,06 & 5,25 & 8,81 & 5,91 & 3,11 \\
\hline \multirow{2}{*}{ Контур № 4 } & $\underline{0,89}$ & $\underline{0,33}$ & $\underline{0,92}$ & $\underline{0,66}$ & $\underline{30,5}$ & $\underline{0,41}$ & $\underline{2,59}$ & $\underline{1}, 01$ & $\underline{0,70}$ \\
\cline { 2 - 10 } & 4,67 & 2,25 & 11,01 & 1,98 & 75,5 & 2,26 & 16,85 & 2,76 & 4,12 \\
\hline \multirow{2}{*}{ Фон } & $\leq 6,0$ & $\underline{0,24}$ & $\underline{9,8}$ & $\underline{0,44}$ & $\leq 13$ & $\underline{0,27}$ & $\underline{8,17}$ & $\underline{5,15}$ & $\underline{0,43}$ \\
\cline { 2 - 9 } & $<24,0$ & 2,55 & 9,25 & 1,37 & 364,5 & 3,30 & 168,33 & 16,11 & 4,54 \\
\hline
\end{tabular}


В первую группу входят элементы, доступные формы которых активно извлекаются растениями $(\mathrm{Bx}>1)$. В рассматриваемом случае это Мо и менее активно $\mathrm{Zn}$. На фоновом участке растения активно поглощали и перемещали в надземную часть $\mathrm{Cd}, \mathrm{Cu}, \mathrm{Mo}, \mathrm{Pb}, \mathrm{Zn}$, что обусловлено низким содержанием их подвижных форм по сравнению с их концентрацией в техногенном песке и почвогрунтах рекультивированных контуров.

Во вторую группу - элементы, подвижные формы которых не полностью извлекаются растениями в связи с избыточностью их содержания, физиологическим ограничением в поглощении или транслокации к надземным органам $(\mathrm{Bx}<1)$. К этой группе относятся большинство изученных нами элементов - $\mathrm{Cd}, \mathrm{Co}, \mathrm{Cu}$, $\mathrm{Mn}, \mathrm{Ni}, \mathrm{Cr}$. Для $\mathrm{Cd}, \mathrm{Co}, \mathrm{Pb}$ и $\mathrm{Cr}$ характерны корневой барьер и слабая транслокация в наземные органы.

Как видно из данных табл. 3, в условиях загрязнения (техногенный песок) значения Вx для надземной массы в отношении $\mathrm{Mo}, \mathrm{Ni}, \mathrm{Pb}, \mathrm{Cr}$ оказались ниже, чем у растений фонового и рекультивированных участков, что свидетельствует о снижении интенсивности их поглощения. Аналогичные выводы ранее были сделаны и другими исследователями [Безель, Жуйкова, 2007; Башмаков, Лукаткин, 2009; Батова и др., 2014]. Данные авторы полагают, что это может быть связано как с уменьшением доступности элементов для растений вследствие изменения кислотности почвенного раствора или взаимного (антагонистического) влияния ионов, так и с активизацией у них механизмов, поддерживающих постоянство микроэлементного состава организма в неблагоприятных эдафических условиях.

Корневая система растений активно поглощает ТМ. Высокие значения Вх отмечены для $\mathrm{Mo}, \mathrm{Cu}, \mathrm{Pb}$, а относительно низкие — для $\mathrm{Co}, \mathrm{Mn}, \mathrm{Ni}$.

Нами были рассчитаны коэффициенты парной корреляции между содержанием ТМ в растениях и их подвижными формами в почве, почвогрунтах (табл. 4).

\section{Таблица 4}

Коэффициенты корреляции содержания ТМ в растениях с количеством обменной формы

\begin{tabular}{|l|c|c|c|c|c|c|c|c|c|}
\hline Часть фитомассы & $\mathrm{Cd}$ & $\mathrm{Co}$ & $\mathrm{Cu}$ & $\mathrm{Mn}$ & $\mathrm{Mo}$ & $\mathrm{Ni}$ & $\mathrm{Pb}$ & $\mathrm{Zn}$ & $\mathrm{Cr}$ \\
\hline Надземная & 0,99 & 0,94 & 0,94 & 0,63 & $-0,16$ & 0,48 & 0,52 & 0,94 & 0,14 \\
\hline Подземная & 0,56 & 0,54 & 0,87 & 0,50 & 0,95 & 0,11 & 0,83 & 0,87 & 0,72 \\
\hline
\end{tabular}

Из таблицы 4 видно, что концентрация $\mathrm{Cu}$ и $\mathrm{Zn}$ в растениях имела очень высокую корреляцию с уровнем их подвижных форм в субстрате. Такая же зависимость выявлена для содержания в надземной массе $\mathrm{Cd}$ и Сo. Средняя корреляция отмечалась для содержания в надземной массе $\mathrm{Mn}, \mathrm{Pb}$ и слабая - $\mathrm{Ni}$. Для Мо и $\mathrm{Cr}$ эта зависимость была очень слабой. Несколько иная зависимость прослеживалась для подземной массы. Так, для большинства ТМ корреляция оценивалась как средняя и высокая, за исключением $\mathrm{Ni}$, где она очень слабая.

Элементами доминантами по содержанию в растениях являются $\mathrm{Mn}, \mathrm{Zn}, \mathrm{Cu}$ и $\mathrm{Pb}$. Таким образом, уровни концентрации ТМ в растениях на исследуемой территории имели зависимость от уровня содержания их подвижных форм. 


\section{Заключение}

1. Содержание обменной формы ТМ превышало ПДК по содержанию $\mathrm{Cd}, \mathrm{Cu}$, $\mathrm{Ni}$ и $\mathrm{Zn}$ в почвогрунтах рекультивированных участков, $\mathrm{Cr}, \mathrm{Ni}$ и $\mathrm{Pb}-$ в техногенном песке и не превышало в фоновой почве.

2. Концентрация ТМ в растениях имела различный уровень и вариабельность. Содержание ТМ в растениях рекультивированных контуров выше, чем в растениях фонового участка.

3. Концентрация ТМ в надземной части растений рекультивированных контуров в большинстве случаев превышала их средние содержания в растительности континентов. Для растений на участке техногенного песка это превышение отмечалось в отношении $\mathrm{Cd}, \mathrm{Mo}$ и $\mathrm{Pb}$, а на фоновом участке - $\mathrm{Cd}, \mathrm{Co}, \mathrm{Mo}$ и $\mathrm{Pb}$. В целом относительно высокое содержание ТМ определено в надземной массе растений, произрастающих на контуре № 1, а минимальное - на фоновом участке и техногенном песке.

4. Концентрация элементов в подземной массе значительно выше, чем в надземной массе. В подземной массе растений относительно максимальная концентрация выявлена на контуре № 1 и техногенном песке, а минимальная - на фоновом участке.

5. Элементами доминантами по содержанию в растениях являются $\mathrm{Mn}, \mathrm{Zn}$, $\mathrm{Cu}$ и $\mathrm{Pb}$.

6. Уровни концентрации ТМ в растениях имели зависимость от уровня содержания их подвижных форм.

7. Значения коэффициента биогеохимической подвижности (Bх) имели широкий диапазон колебаний для подземной массы и относительно узкий для надземной массы.

8. Доступные формы Mo, $\mathrm{Zn}$ активно извлекались растениями $(\mathrm{Bx}>1)$. На фоновом участке растения активно поглощали и перемещали в надземную часть $\mathrm{Cd}, \mathrm{Cu}, \mathrm{Mo}, \mathrm{Pb}, \mathrm{Zn}$.

9. Большинство изученных элементов ( $\mathrm{Cd}, \mathrm{Co}, \mathrm{Cu}, \mathrm{Mn}, \mathrm{Ni}, \mathrm{Cr}, \mathrm{Pb})$ имели ограничения в поглощении или транслокации к надземным органам $(\mathrm{Bx}<1)$. Для $\mathrm{Cd}, \mathrm{Co}, \mathrm{Pb}$ и $\mathrm{Cr}$ характерны корневой барьер и слабая транслокация в надземные органы.

\section{Литература}

1. Бардамова И. В., Гергенов М. К. Влияние горнорудного производства на состояние поверхностных вод района Джидинских месторождений // Геология Забайкалья: материалы II Всерос. молодеж. науч. конф. Улан-Удэ: Изд-во БНЦ, 2012. С. 18-19.

2. Состояние травянистой растительности и накопление тяжелых металлов растениями, произрастающими в условиях техногенного загрязнения почвы / Ю. В. Батова и [др.] // Вестник Тамбовского университета. Сер. Естественные и технические науки. 2014. Т. 19, вып. 5. С. 1642-1645.

3. Состояние травянистой растительности и накопление тяжелых металлов растениями, произрастающими в условиях техногенного загрязнения почвы / Ю. В. Батова [и др.] // Вестник Тамбовского университета. Серия: Естественные и технические науки, 2014. Т. 19, Вып.5, С. 1642-1645

4. ГОСТ 17.5.1.03-86 Классификация вскрышных и вмещающих пород для биологической рекультивации земель. 
Сосорова С. Б., Лаврентьева И. Н., Болонева Л. Н., Убугунов В. Л., Цыремпилов Э. Г. Тяжелые металлы в растениях на территории деятельности Джидинского вольфрамо-молибденового комбината

5. Дмитриева Н. Г. Воздействие отходов Джидинского вольфрамо-молибденового комбината на состояние природной среды г. Закаменска // Устойчивое развитие в Восточной Азии: актуальные эколого-географические и социально-экономические проблемы: сб. материалов междунар. науч.-практ. конф., посвящ. 30-летию высшего географического образования и 60-летию фундаментальной географической науки в Бурятии / науч. ред. Ц. Д. Гончикова. Улан-Удэ, 2018. С. 282-285.

6. Добровольский В. В. Основы биогеохимии: учебник для студ. высш. учеб. заведений. М.: Академия, 2003. 400 c.

7. Оценка состояния почв и растительности г. Закаменска (Бурятия): последствия деятельности Джидинского вольфрамо-молибденового комбината / С. Г. Дорошкевич [и др.] // Геоэкология. Инженерная геология, гидрогеология, геокриология. 2016. № 5. С. 427-441.

8. Ильин В. Б., Сысо А. И. Тяжелые металлы и неметаллы в системе почва-растение. Новосибирск: Изд-во СО РАН, 2012. 220 с.

9. Иметхенов А. Б., Иметхенов О. А., Иметхенова О. В. Влияние техногенных песков Джидинского вольфрамо-молибденового комбината (Джидакомбината) на окружающую среду (Республика Бурятия) // Вестник ВСГУТУ. 2016. № 6 (63). С. 47-53.

10. Кабата-Пендиас А., Пендиас Х. Микроэлементы в почвах и растениях: пер. с англ. М.: Мир, 1989. 439 с.

11. Касимов Н. С., Власов Д. В. Кларки химических элементов как эталоны сравнения в экогеохимии // Вестник Московского университета. Сер. 5. География. 2015. № 2. С. 7-17.

12. Классификация и диагностика почв России. Смоленск: Ойкумена, 2004. 343 с.

13. Кожевникова Н. М., Куликов А. И. Содержание и распределение подвижных форм меди и цинка в микрозонах прикорневого слоя почвы пастбищного ценоза в техногенных ландшафтах Джидинского вольфрамо-молибденового комбината // Вестник Бурятской государственной сельскохозяйственной академии им. В. Р. Филиппова. 2010. № 1 (18). C. 90-95.

14. Козыбаева Ф. Е., Мурсалимова Э. А. Биопродуктивность и содержание тяжелых металлов в фитоценозах рекультивированных промышленных отвалов // Гидрометеорология и экология. 2004. № 4 (35). С. 88-95.

15. Методические указания по определению тяжелых металлов в почвах сельхозугодий и продукции растениеводства. М.: ЦИНАО, 1992. 61 с.

16. Накопление и распределение тяжелых металлов в растениях зоны техногенеза / Т. М. Минкина [и др.] // Агрохимия. 2013. № 9. С. 65-75.

17. Перельман А. И., Касимов Н. С. Геохимия ландшафта. М.: Астрея. 2000, 1999. 768 с.

18. Миграция тяжелых металлов от очага загрязнения в зависимости от взаимосвязей в ландшафте / А. В. Писарева [и др.]. // Вестник технологического университета. 2017. T. 20, № 6. С. 160-163.

19. СанПиН 2.1.7.573-96. Гигиенические требования к использованию сточных вод и их осадков для орошения и удобрения.

20. СанПиН 4266-87. Методические указания по оценке степени опасности загрязнения почвы химическими веществами.

21. Геоэкологическая оценка рекультивированных территорий деятельности Джидинского вольфрамо-молибденового комбината (Республика Бурятия) / С. Б. Сосорова [и др.] // Проблемы региональной экологии. 2018. № 6. С.69-72.

22. Gerasimova L., Eremina I., Kuklina A. Assessment of Chemical Soil Pollution by Biotesting // The Scientific Heritage. 2020. № 45. P. 17-20. 
HEAVY METALS IN PLANTS ON THE TERRITORY OF DZHIDA

TUNGSTEN-MOLYBDENUM COMBINE (WESTERN TRANSBAIKAL REGION)

S. B. Sosorova, I. N. Lavrentyeva, L. N. Boloneva, V. L. Ubugunov, E. G. Tsyrempilov

\section{Soelma B. Sosorova}

Cand. Sci. (Biol.),

Institute of General and Experimental Biology SB RAS

6 Sakhyanovoy St., Ulan-Ude 670047, Russia

soelma_sosorova@mail.ru.

Irina N. Lavrentieva

Cand. Sci. (Biol.),

Institute of General and Experimental Biology SB RAS

6 Sakhyanovoy St., Ulan-Ude 670047, Russia

lira1973@mail.ru.

Ludmila N. Boloneva

Cand. Sci. (Biol.),

Institute of General and Experimental Biology SB RAS

6 Sakhyanovoy St., Ulan-Ude 670047, Russia

ldm-boloneva@mail.ru.

Vasiliy L. Ubugunov

Cand. Sci. (Biol.),

Institute of General and Experimental Biology SB RAS

6 Sakhyanovoy St., Ulan-Ude 670047, Russia

ubugunovv@mail.ru

Enkhe G. Tsyrempilov

Cand. Sci. (Biol.),

Institute of General and Experimental Biology SB RAS

6 Sakhyanovoy St., Ulan-Ude 670047, Russia

enhetsyrempilov@mail.ru

Abstract. The article studies the concentration of heavy metals (HM) in plants on territory of Dzhida tungsten-molybdenum combine (Western Transbaikal Region). The objects of the study were plants growing on alluvial dark humus soil (Fluvisols) - the background area, on man-made sand and soils of reclaimed areas. The content of the exchange form of TM exceeded the MPC for the content of $\mathrm{Cd}, \mathrm{Cu}, \mathrm{Ni}$ and $\mathrm{Zn}$ in the soils of reclaimed areas, $\mathrm{Cr}$, Ni and $\mathrm{Pb}$ - in man-made sand and did not exceed in the background soil. The concentration of HM in plants had different levels and variability. It was found that in the aboveground part of the plants of reclaimed contours, the concentrations of HM in most cases exceeded their average content in the vegetation of continents. For plants in the area of man-made sand, this excess was observed for $\mathrm{Cd}, \mathrm{Mo}$ and $\mathrm{Pb}$, and in the background area - for $\mathrm{Cd}, \mathrm{Co}$, Mo and $\mathrm{Pb}$. In general, we have determined a relatively high content of HM in the aboveground mass of plants growing in the contour No. 1, and a minimum content in the background area and man-made sand. The concentration of elements in the underground mass is much higher than 
Сосорова С. Б., Лаврентьева И. Н., Болонева Л. Н., Убугунов В. Л., Цыремпилов Э. Г. Тяжелые металлы в растениях на территории деятельности Джидинского вольфрамо-молибденового комбината

in the aboveground mass. In the underground mass of plants, the relatively maximum concentration was found on contour No. 1 and man-made sand, while the minimum concentration was found in the background area. The dominant elements in plants were $\mathrm{Mn}$, $\mathrm{Zn}, \mathrm{Cu}$, and $\mathrm{Pb}$. The levels of $\mathrm{HM}$ concentration in plants depend on the content of their mobile forms. The values of the biogeochemical mobility coefficient $(\mathrm{Bx})$ had a wide range of fluctuations for the underground mass and a relatively narrow range for the aboveground mass. The available forms of Mo and $\mathrm{Zn}$ were actively extracted by plants $(\mathrm{Bx}>1)$. In the background area, plants actively absorbed and moved $\mathrm{Cd}, \mathrm{Cu}, \mathrm{Mo}, \mathrm{Pb}, \mathrm{Zn}$ to the aboveground part. Most of the studied elements $(\mathrm{Cd}, \mathrm{Co}, \mathrm{Cu}, \mathrm{Mn}, \mathrm{Ni}, \mathrm{Cr})$ had a value of $\mathrm{Bx}<1$.

Keywords: heavy metals; plants; pollution; soils; man-made sand; background area.

Статья поступила в редакцию 23.12.20; одобрена после редактирования 16.12.20; принята к публикации 18.12.20. 